\title{
Section XV: Cultural Property
}

\begin{abstract}
Rule 130
"Cultural property" means movable or immovable property, whether secular or religious and irrespective of origin or ownership, which is of great importance to the cultural heritage of every people. Examples include buildings and other monuments of historic, artistic or architectural significance; archaeological sites; artworks, antiquities, manuscripts, books, collections thereof, and collections of reproductions thereof; scientific collections; and archives. The term "cultural property" extends to buildings whose main and effective purpose is to preserve or exhibit movable cultural property and to refuges intended to shelter it, as well as to centres containing a large amount of movable or immovable cultural property.
\end{abstract}

\section{Commentary}

1. The definition of "cultural property" in this Rule is based on Article 1 of the 1954 Hague Convention for the Protection of Cultural Property in the Event of Armed Conflict.

2. The phrase "of every people" in Article 1 of the 1954 Hague Convention is capable on its face of two meanings, i.e. "of all peoples jointly" or "of each respective people". The practice of States Parties to the Convention varies in terms of the interpretation of the phrase, and opinions are therefore divided as to the correct approach. Whether specific property is of sufficient importance is for all relevant States, including the State on whose territory it is situated, to determine and is an assessment that must be made in good faith.

3. Where they are not "cultural property" in the technical sense, buildings such as educational institutions, libraries, archives and places of worship, along with objects such as artworks and books, are still protected by LOAC as civilian objects. That said, as is the case with any other object of a civilian nature, the 
items referred to in this paragraph may become military objectives, e.g. by virtue of use.

4. These Rules can also apply in occupied territory, see Article 5 of the 1954 Hague Convention.

\section{Rule 131}

In an armed conflict, it is prohibited to make any use of cultural property or of its immediate surroundings for purposes likely to expose the property to destruction or damage unless this is imperatively required by military necessity.

\section{Commentary}

1. This Rule is based on Articles 4(1) and (2) as well as Article 19(1) of the 1954 Hague Convention. See also Article 16 of AP/II. The Rule is consistent with customary LOAC protections of cultural property applicable in both international and non-international armed conflicts.

2. Subject to waiver for reasons of imperative military necessity, uses of cultural property or its immediate surroundings that are prohibited by Rule 131 include, by way of example:

a. Positioning a missile battery or anti-aircraft gun inside or alongside a historic structure, whether to take tactical advantage of the location or to shield the battery or gun from attack;

b. Incorporating a historic structure into a defensive line; and

c. Using a historic structure as a field headquarters or armoury.

3. The use of cultural property or that of its immediate surroundings need not expose it to attack for it to violate the Rule. Rule 131 prohibits, subject to imperative military necessity, any use of cultural property or of its immediate surroundings for purposes likely to expose the property to damage resulting in the likelihood of material harm to cultural property.

4. In all cases, any use of cultural property or of its immediate surroundings for purposes likely to expose the property to destruction or damage is not prohibited if imperatively required by military necessity.

5. A party to the conflict's use of cultural property or of its immediate surroundings for purposes likely to expose the property to destruction or damage does not automatically relieve an opposing party of its obligation not to attack the property (see Rule 132(a)). That is, use contrary to Rule 131 does not of itself make it lawful to attack cultural property. It is prohibited to attack cultural property unless it becomes a lawful object of attack (see Rules 9 and 10 with Commentaries) and unless military necessity imperatively requires waiver of the obligation to refrain from any act of hostility directed against such property (see Rule 132(a)).

6. Destruction of property that does not qualify as cultural property is dealt with in chapter "Section XI: Destruction of Property". 


\section{Rule 132}

(a) It is prohibited to make cultural property the object of attack unless it is a military objective and military necessity imperatively requires waiver of the obligation to refrain from any act of hostility directed against such property.

\section{Commentary}

1. This Rule is based on Articles 4(1) and (2) of the 1954 Hague Convention. However, the concept of military objective is rooted in customary international law and it has been introduced in Article 6(a)(i) and (ii) of the Second Protocol (of 1999) to the 1954 Hague Convention. It must be noted, nevertheless, that the Second Protocol is not as widely ratified as the original Convention.

(b) Where cultural property becomes a military objective and military necessity imperatively requires waiver of the obligation to refrain from any act of hostility directed against it, any decision to attack the property should be taken only by an officer of appropriate seniority.

\section{Commentary}

1. This paragraph of Rule 132 is based on the general practice of States. When parties to the conflict are bound by the Second Protocol (of 1999) to the 1954 Hague Convention, Article 6(c) provides in mandatory terms that any decision to invoke military necessity to attack cultural property must be taken by an officer commanding a force equivalent in size to at least a battalion, unless circumstances do not permit.

(c) Where cultural property becomes a military objective and military necessity imperatively requires waiver of the obligation to refrain from any act of hostility directed against it, a party to the conflict should give advance warning whenever circumstances permit.

\section{Commentary}

1. Where parties to the conflict are bound by the Second Protocol (of 1999) to the 1954 Hague Convention, Article 6(d) of the Protocol specifies that, in the event that cultural property becomes a military objective and there is no feasible alternative to attacking it, a party must give advance warning before an attack whenever circumstances permit.

2. Where cultural property is being used in support of military action, advance warning grants the opposing forces an opportunity to cease such use, with the consequence that the property will no longer constitute a military objective and must be spared attack. The warning should demand the termination of the use and give the opposing forces reasonable time to terminate such use. 
3. Advance warning grants an opposing party an opportunity to take practical measures to minimize damage to the cultural property or to any movable cultural property housed in it, including by removing the latter to a place of safety or providing for adequate in situ protection (see Rule 134(a)).

\section{Rule 133}

(a) It is prohibited to launch an attack that may be expected to cause collateral damage to cultural property that would be excessive in relation to the concrete and direct military advantage anticipated.

\section{Commentary}

1. This Rule is based on the principle of proportionality, which is commented upon in general in paragraphs 1 and 6 of the Commentary to Rule 11 and in paragraph 1 of the Commentary to Rule 14 . In the specific context of cultural property, the same substantive rule is codified in Article 7(c) of the Second Protocol to the 1954 Hague Convention. It is applicable in both international and non-international armed conflicts, in accordance with Articles 3 and 22(1) of the Second Protocol.

2. As applied to cultural property, the proportionality calculus involves qualitative as much as quantitative considerations. The measure of collateral damage to cultural property is a question not just of cubic metres but also of the cultural value of the property likely to be harmed. In this light, it is significant that movable or immovable property qualifying as cultural property is, by definition, of great importance to the cultural heritage of peoples (see Rule 130).

(b) Parties to the conflict must take feasible precautions in the choice of means and methods of attack with a view to avoiding, and in any event minimizing, collateral damage to cultural property.

\section{Commentary}

1. This Rule expresses the LOAC duty to take feasible precautions, which is commented upon in general in paragraphs 1 and 6 the Commentary to Rule 11 and in paragraph 1 of the Commentary to Rule 14. The corresponding duty is expressed in Article 7(b) of the Second Protocol (of 1999) to the 1954 Hague Convention for States Parties and is applicable in both international and non-international armed conflicts for such States, in accordance with Articles 3 and 22(1) of the Second Protocol.

\section{Rule 134}

Parties to the conflict liable to be attacked should, to the maximum extent feasible:

\section{Commentary}

1. Subparagraph (a) is derived from Article 8(a) of the Second Protocol (of 1999) to the 1954 Hague Convention, as well as Article 58(a) of AP/I and customary 
LOAC. For parties to the conflict bound by the Second Protocol to the 1954 Hague Convention, the obligation in (a) is binding in both international and non-international armed conflict, by virtue of Articles 8(a) and 22(1) of the Second Protocol.

2. Subparagraph (b) is derived from Article 8(b) of the Second Protocol to the 1954 Hague Convention. For parties to the conflict bound by the Second Protocol to the 1954 Hague Convention, the obligation in (b) is binding in non-international armed conflict as well by virtue of Articles 8 (b) and 22(1) of the Second Protocol.

\section{(a) Remove movable cultural property from the vicinity of military objec- tives or provide for adequate in situ protection; and}

\section{Commentary}

1. The fact that the party subject to attack has not taken the precautions specified in Rule 134(a) does not relieve the attacking party of its obligations in attack under Rules 132 and 133.

2. The related rule in Article 3 of the 1954 Hague Convention stipulates that States Parties must take such measures as they consider appropriate to prepare in time of peace for the safeguarding of cultural property situated within their own territory against the foreseeable effects of armed conflict.

(b) Avoid locating military objectives near cultural property.

\section{Commentary}

1. Rule 134(b) requires, to the extent that the military situation and other relevant factors admit, that a party refrain from positioning in the vicinity of cultural property any likely military target. What is to be considered "near" cultural property depends on the circumstances of each case.

2. The fact that the party subject to attack has not taken the precautions specified in Rule 134(b) does not relieve the attacking party of its obligations in attack under Rules 132 and 133.

\section{Rule 135}

(a) Personnel exclusively engaged on behalf of a party to the conflict in the protection of cultural property should not be made the object of attack so far as is consistent with the security interests of the opposing party.

\section{Commentary}

1. Article 15 of the 1954 Hague Convention provides that, as far as is consistent with the security of the opposing party, personnel engaged in the protection of cultural property must, in the interest of such property, be respected. Crossreference to Article 17(2)(b) and (c) of the Convention indicates that the 
personnel in question are those engaged on behalf of a party to the conflict. One consequence of Article 15 is that such personnel must not be made the object of attack. This obligation is reflected in the present Rule.

2. The protection accorded by Rule 133(a) is available only if the relevant personnel are engaged exclusively in the protection of cultural property and not also, for example, in the protection of military objectives.

3. A party to the conflict may, in fulfilment of Article 3 of the 1954 Hague Convention and as expressly envisaged in Article 5 of the Second Protocol (of 1999), designate competent authorities responsible for the safeguarding of cultural property against the foreseeable effects of armed conflict. A party to the conflict may also, as implied by Article 8(4) of the Convention, specially empower "armed custodians" to guard cultural property. The Group of Experts were divided as to whether members of the armed forces may be engaged in the protection of cultural property and whether they would then be protected against attack.

4. It is unclear whether Article 15 of the 1954 Hague Convention extends to any members of a party's armed forces acting as "armed custodians" of cultural property within the meaning of Article 8(4) or to the "services or specialist personnel" established within a party's armed forces pursuant to Article 7(2).

5. In accordance with Article 21 of the Regulations for the Execution of the 1954 Hague Convention annexed to the Convention, personnel engaged in the protection of cultural property may wear an armlet bearing the distinctive emblem of cultural property (see Rule 136(a)), issued and stamped by the competent authorities of the State on whose behalf they are engaged, and must carry a special identity card bearing the emblem and the embossed stamp of the competent authorities. The precise appearance of the card is a matter for each State, although the information it contains is specified in Article 21 of the Regulations.

(b) Such personnel lose their protection if and for such time as they are directly participating in hostilities.

\section{Commentary}

1. The notion of DPH is addressed in general in chapter "Section VII: Civilians Directly Participating in Hostilities".

\section{Rule 136}

(a) Parties to the conflict may mark cultural property with a distinctive emblem.

\section{Commentary}

1. A distinctive emblem is created in Article 16(1) of the 1954 Hague Convention. 
2. As provided for in Article 6 of the 1954 Hague Convention, States Parties to the Convention are expressly permitted to affix the emblem to or otherwise depict it on cultural property to facilitate the property's recognition as cultural property. This is reflected in Rule 136(a).

3. Article 17(4) of the Convention stipulates that the distinctive emblem may not be placed on any immovable cultural property unless at the same time there is displayed an authorization duly dated and signed by the competent authority of the State Party in question.

4. Distinctive marking of cultural property is not obligatory, either under Article 6 of the 1954 Hague Convention or under Rule 136(a). Consequently, the fact that property does not bear the emblem does not mean that it is not cultural property protected by the 1954 Hague Convention. Nor does it mean that it is not protected as cultural property under customary international law. In practice, the marking of cultural property with the distinctive emblem is rare.

5. It is not unlawful for a party to the conflict that is not a State Party to the 1954 Hague Convention to mark cultural property with the emblem.

\section{(b) The deliberate misuse of the distinctive emblem in an armed conflict is prohibited.}

\section{Commentary}

1. In accordance with both Article 17(3) of the 1954 Hague Convention and Article 38(1) of AP/I, and as restated in this Rule, the deliberate misuse during armed conflict of the distinctive emblem of cultural property is prohibited.

\section{Rule 137 \\ The foregoing rules are without prejudice to any 'special' or 'enhanced' protection in accordance with applicable treaties.}

\section{Commentary}

1. This Rule preserves the prohibitions reflected in Article 8 of the 1954 Hague Convention ("special protection") and in Article $10 \mathrm{ff}$. of the Second Protocol (of 1999) to the 1954 Hague Convention ("enhanced protection").

Open Access This chapter is licensed under the terms of the Creative Commons Attribution 4.0 International License (http://creativecommons.org/licenses/by/4.0/), which permits use, sharing, adaptation, distribution and reproduction in any medium or format, as long as you give appropriate credit to the original author(s) and the source, provide a link to the Creative Commons licence and indicate if changes were made.

The images or other third party material in this chapter are included in the chapter's Creative Commons licence, unless indicated otherwise in a credit line to the material. If material is not included in the chapter's Creative Commons licence and your intended use is not permitted by statutory regulation or exceeds the permitted use, you will need to obtain permission directly from the copyright holder.

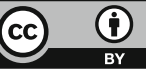

